National Water Quality Assessment Program

\title{
Selected Historic Agricultural Data Important to Environmental Quality in the United States
}
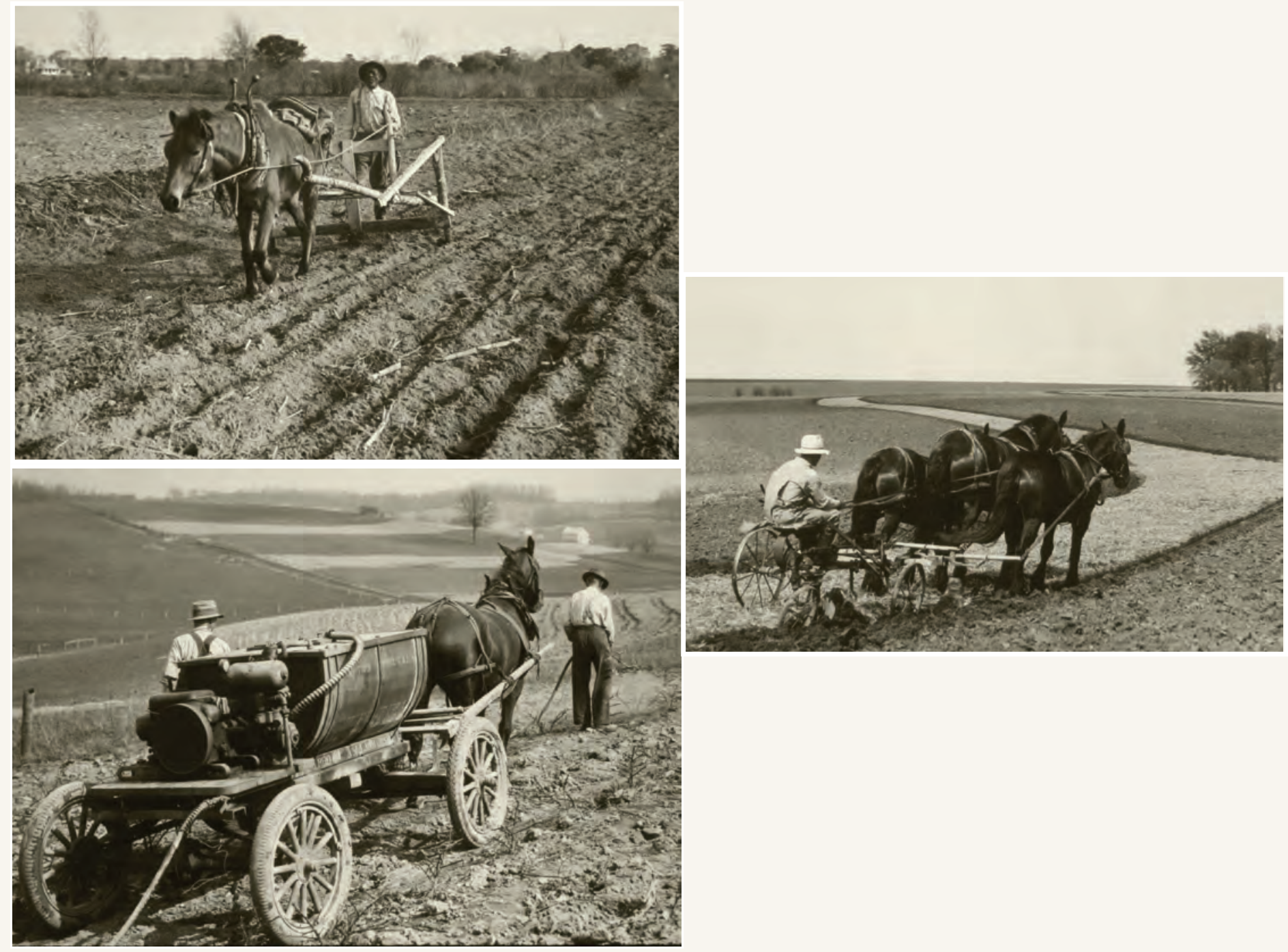

Data Series 689 
All cover photos courtesy of the National Resources Conservation Service.

Top left: A farmer uses a primitive moldboard plow to till his farmland in the District of Columbia (date unknown).

Center right: An early use of contour farming in lowa (date unknown).

Bottom left: Farmers spray raspberry bushes planted on the contour on a farm near Danville, Ohio, in 1939. 


\section{Selected Historic Agricultural Data Important to Environmental Quality in the United States}

By Katia M. Grey, Paul D. Capel, Nancy T. Baker, and Gail P. Thelin

National Water Quality Assessment Program

Data Series 689 


\title{
U.S. Department of the Interior \\ KEN SALAZAR, Secretary \\ U.S. Geological Survey \\ Marcia K. McNutt, Director
}

\author{
U.S. Geological Survey, Reston, Virginia: 2012
}

For more information on the USGS - the Federal source for science about the Earth, its natural and living resources, natural hazards, and the environment, visit http://www.usgs.gov or call 1-888-ASK-USGS.

For an overview of USGS information products, including maps, imagery, and publications, visit http://www.usgs.gov/pubprod

To order this and other USGS information products, visit http://store.usgs.gov

Any use of trade, firm, or product names is for descriptive purposes only and does not imply endorsement by the U.S. Government.

Although this information product, for the most part, is in the public domain, it also may contain copyrighted materials as noted in the text. Permission to reproduce copyrighted items must be secured from the copyright owner.

Suggested citation:

Grey, K.M., Capel, P.D., Baker, N.T., and Thelin, G.P., 2012, Selected historic agricultural data important to environmental quality in the United States: U.S. Geological Survey Data Series Report 689, 2 p. plus tables. 


\section{Contents}

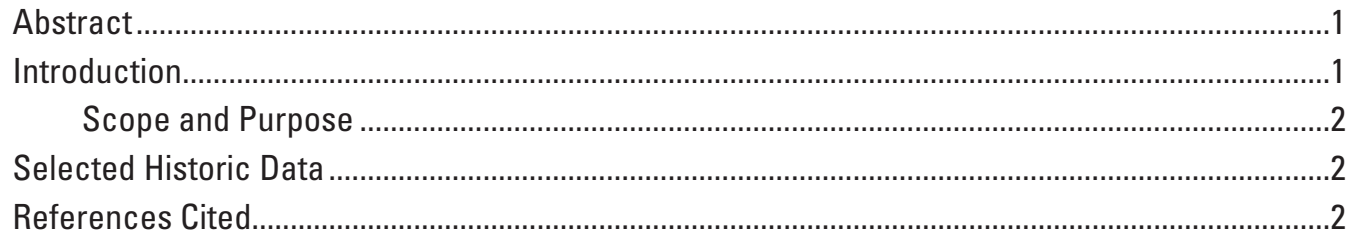

\section{Tables}

[Tables are available in a separate Excel file]

1. Temporal changes in labor hours, acres planted, and farm equipment used in the production of corn, cotton, and wheat in the United States, 1850-1987.

2. Timeline of selected agricultural events in the United States that are broadly related to environmental quality.

3. Selected historic agricultural data important to environmental quality in the United States, 1850-2010.

4. National pesticide use in crop agriculture in the United States in 2009, by active ingredient. 



\title{
Selected Historic Agricultural Data Important to Environmental Quality in the United States
}

\author{
By Katia M. Grey', Paul D. Capel'2, Nancy T. Baker ${ }^{2}$, and Gail P. Thelin ${ }^{2}$
}

\begin{abstract}
This report and the accompanying tables summarize some of the important changes in American agriculture in the form of a timeline and a compilation of selected annual time-series data that can be broadly related to environmental quality. Although these changes have been beneficial for increasing agricultural production, some of them have resulted in environmental concerns. The agriculture timeline is divided into four categories (1) crop and animal changes, (2) mechanical changes, (3) biological and chemical changes, and (4) regulatory and societal changes. The timeline attempts to compile events that have had a lasting impact on agriculture in the United States. The events and data presented in this report may help to improve the connections between agricultural activist and environmental concerns.
\end{abstract}

\section{Introduction}

In 1840, the United States conducted its first agricultural census (U.S. Department of Agriculture, Census of Agriculture, 2012). Early agricultural data pertained to rural population, labor on farms, crop acreage planted, and crop yield. As agriculture expanded through land modification (drainage), technological advances (mechanization), chemical use (fertilizers and pesticides), and plant and animal breeding (advanced genetics), the census collected additional related information. Since 1997, the census of agriculture has been conducted by the U.S. Department of Agriculture's (USDA) National Agricultural Statistics Service (U.S. Department of Agriculture, National Agricultural Statistics Service, 2012). In addition, many other Federal, state, and local agencies, academic institutions, and private corporations have and continue to collect a variety of agricultural data. The USDA collects a wide array of crop and livestock information published through the National Agricultural Statistics Service (U.S. Department of
Agriculture, National Agricultural Statistics Service, 2012). The USDA Economic Research Service publishes selected economically related agricultural data (U.S. Department of Agriculture, Economic Research Service, 2012).

Throughout much of American history, the major crops have been corn, predominantly for human food and animal feed; wheat, for human food; oats, for animal feed; cotton, for fiber; and, more recently soybeans, for feed and food (as presented in the accompanying timeline and data tables). Important livestock include cattle, swine, and poultry. New technologies developed since the 1950s allowed the development and expansion of feeding operations. Although agricultural expansion and intensification have been beneficial to increasing production, their cumulative effects have caused environmental concerns.

Mechanical inventions such as metal plows, harvesters, and the cotton gin transformed agriculture. Railroads brought agriculture products to market, and steam-powered machines opened the way for drainage and irrigation projects. Internal combustion engine technology allowed for self-propelled tractors and harvesters. Electrification and refrigeration brought major changes to animal agriculture and opened distant markets.

The development and availability of chemical fertilizers allowed for intensification in crop agriculture and increased yields. Pesticides were developed to control weeds, insects, fungi, and other pests. Advances in biotechnology have allowed agricultural crops to be genetically embedded with protective traits against drought, insects, and specific herbicides.

Federal programs supporting agricultural infrastructure and crop research were important to agricultural expansion. As agriculture expanded, laws were passed for the protection of people and the environment. Erosion and water-quality issues resulting from agricultural activity prompted additional mandates and government incentives to manage land in a more sustainable manor.

\footnotetext{
1. University of Minnesota.

2. U.S. Geological Survey.
} 


\section{Scope and Purpose}

This report summarizes some of the important events in American agriculture and compiles selected annual time-series data that are broadly related to environmental quality. The body of the report comprises four tables. Data were compiled from existing databases and previously published reports.

\section{Selected Historic Data}

Historic agricultural data important to water quality are presented in a series of four tables. Temporal changes in production methods of corn, cotton, and wheat, for the time period 1850-1987, are presented in table 1. Selected important events in crop and animal agriculture from 1500 to 2011 are shown in a timeline in table 2 . The events shown in table 2 are grouped as mechanical changes, crop and animal changes, biological and chemical changes, and regulatory and societal changes. A compilation of selected annual time-series data that can be broadly related to environmental quality is presented in table 3 . The time-series data were taken verbatim from their sources, except that the units of measurement were changed from inch-pound to metric. Finally, the national agricultural pesticide use data for 2009 are presented in table 4. This table classifies individual pesticides into "categories of use" to provide a context for the data presented in table 3 .

\section{References Cited}

U.S. Department of Agriculture, National Agricultural Statistics Service, 2012: assessed April 12, 2012, at http://www.nass.usda.gov/.

U.S. Department of Agriculture, Census of agriculture, 2012, historical census: assessed April 12, 2012, at http://www. agcensus.usda.gov/Publications/Historical_Publications/ index.php.

U.S. Department of Agriculture, Economic Research Service, 2012: assessed April 12, 2012, at http://www.ers.usda.gov/.

\section{Tables}

Tables 1-4 are available in a separate, downloadable Excel file. 



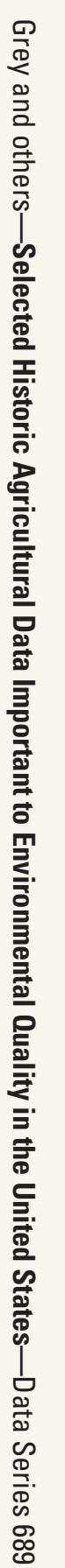

